\title{
Ab initio and RRKM/Master Equation Analysis of the Photolysis and Thermal Unimolecular
}

\section{Decomposition of Bromoacetaldehyde}

\author{
Ibrahim Sadiek $^{\mathrm{a}, \mathrm{b}}$, Gernot Friedrichs ${ }^{\mathrm{b}, \mathrm{c}}$, and Yasuyuki Sakai*d \\ ${ }^{a}$ Institute of Physical Chemistry, University of Kiel, 24118 Kiel, Germany \\ ${ }^{\mathrm{b}}$ Leibniz Institute for Plasma Science and Technology, 17489 Greifswald, Germany \\ ${ }^{\mathrm{c}}$ KMS Kiel Marine Science - Centre for Interdisciplinary Marine Sciences, University of Kiel, 24118, Kiel, \\ Germany \\ ${ }^{\mathrm{d}}$ Department of Mechanical System Engineering, Ibaraki University, 316-8511 Ibaraki, Japan \\ ibrahim.sadiek@inp-greifswald.de \\ friedrichs@phc.uni-kiel.de \\ yasuyuki.sakai.qr80@vc.ibaraki.ac.jp
}

\section{Supplemental Information}

A. Quantum Chemical Calculations

B. Potential Energy Surface: Discussion of Minor Reaction Channels

C. UV absorption reference spectra of halogenated acetaldehydes

D. Multi-Channel Thermal Unimolecular Decomposition Rate Constants 


\section{A. Quantum Chemical Calculations}

\section{A1. Internal Rotor Analysis}
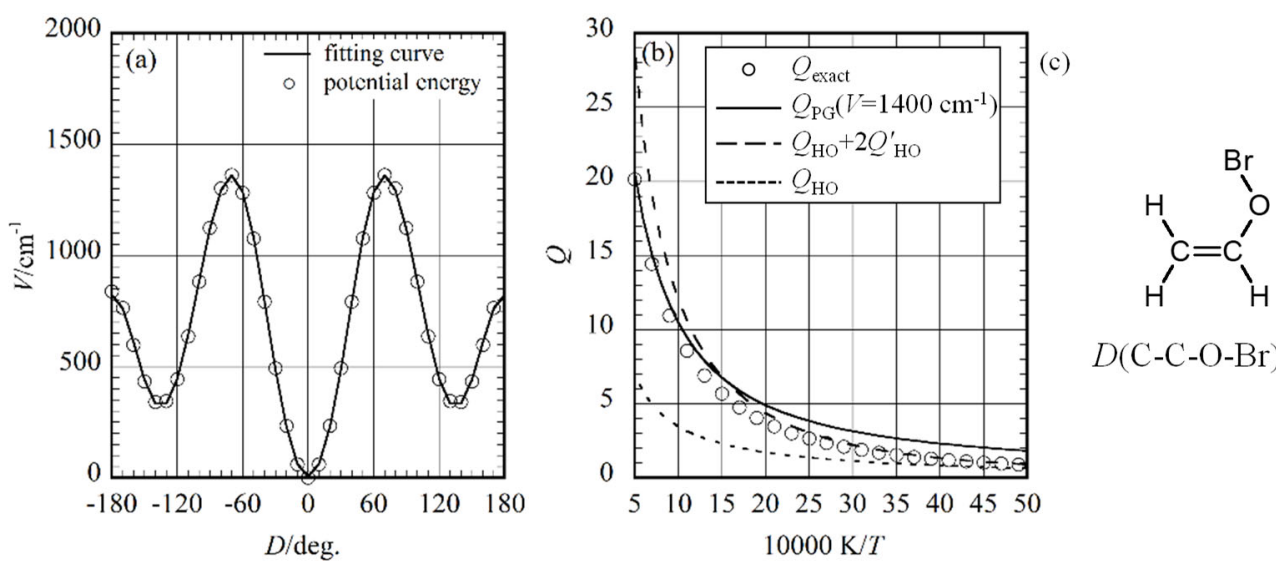

$D(\mathrm{C}-\mathrm{C}-\mathrm{O}-\mathrm{Br})=0$

Figure S1. Internal rotor analysis of the $\mathrm{C}-\mathrm{O}$ bond in $\mathrm{CH}_{2} \mathrm{CHOBr}$. (a) Potential energy (o) calculated by the method of B3LYP/6-31G(2d,p) and its Fourier fitting curve (solid line) as a function of dihedral angle $D(\mathrm{C}$ C-O-Br). (b) Partition function of internal rotor calculated from eigenstate energies ( $\left.Q_{\text {exact }}\right)$, harmonic oscillator of lowest conformer $\left(Q_{\mathrm{HO}}\right)$, harmonic oscillator of all conformers $\left(Q_{\mathrm{HO}^{+}}+2 Q^{\prime}{ }_{\mathrm{HO}}\right)$, and Pitzer-Gwinn $\left(Q_{\mathrm{PG}}\right)$ approximations, (c) chemical structure at dihedral angle $D(\mathrm{C}-\mathrm{C}-\mathrm{O}-\mathrm{Br})=0$.
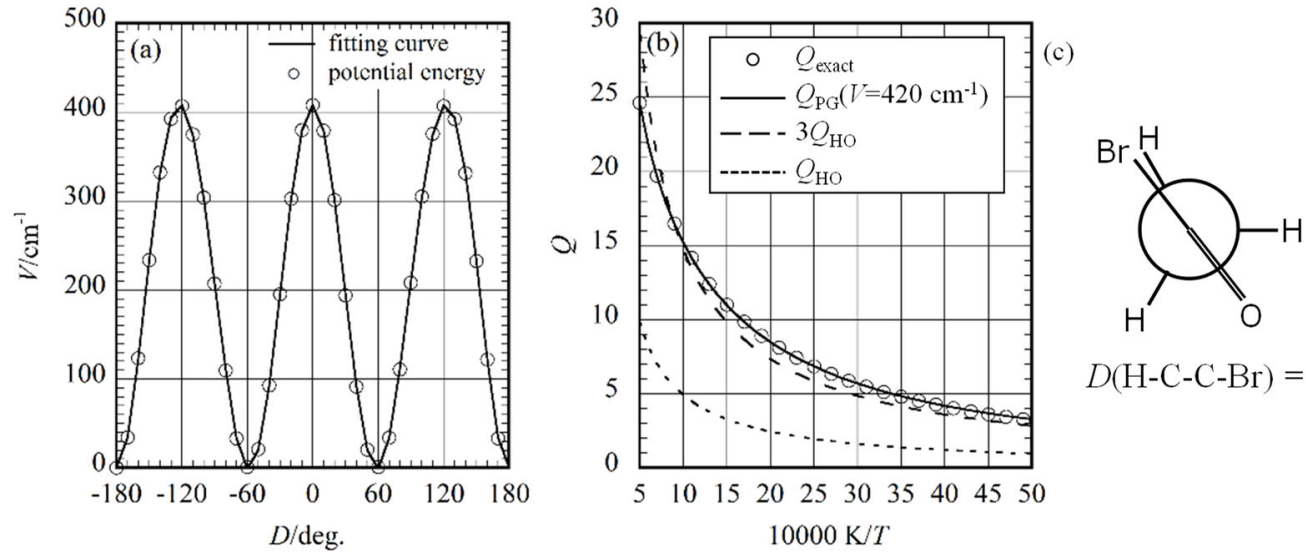

$D(\mathrm{H}-\mathrm{C}-\mathrm{C}-\mathrm{Br})=0$

Figure S2. Internal rotor analysis of the $\mathrm{C}-\mathrm{C}$ bond in $\mathrm{CH}_{3} \mathrm{COBr}$. (a) Potential energy ( $\circ$ ) calculated by the method of B3LYP/6-31G(2d,p) and its Fourier fitting curve (solid line) as a function of dihedral angle $D(\mathrm{H}-$ C-C-Br). (b) Partition function of internal rotor calculated from eigenstate energies ( $\left.Q_{\text {exact }}\right)$, harmonic oscillator of lowest conformer $\left(Q_{\mathrm{HO}}\right)$, harmonic oscillator of all conformers $\left(3 Q_{\mathrm{HO}}\right)$, and Pitzer-Gwinn $\left(Q_{\mathrm{PG}}\right)$ approximations, (c) chemical structure at dihedral angle $D(\mathrm{H}-\mathrm{C}-\mathrm{C}-\mathrm{Br})=0$. 

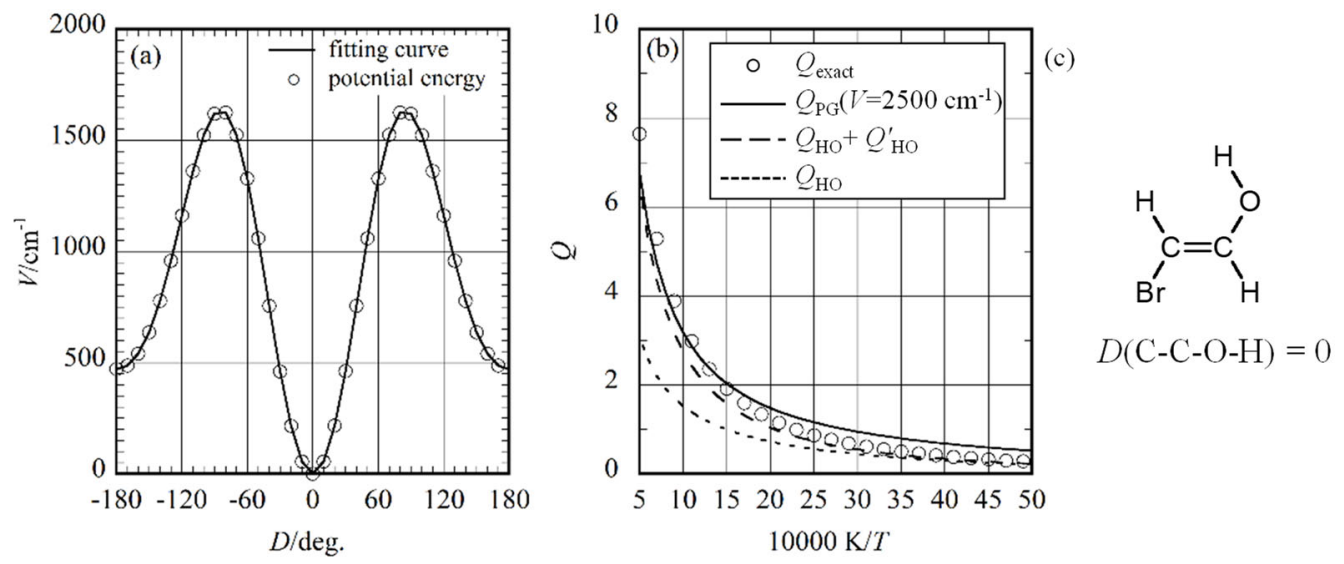

Figure S3. Internal rotor analysis of the $\mathrm{C}-\mathrm{O}$ bond in transBrCHCHOH. (a) Potential energy (o) calculated by the method of B3LYP/6-31G(2d,p) and its Fourier fitting curve (solid line) as a function of dihedral angle $D(\mathrm{C}-\mathrm{C}-\mathrm{O}-\mathrm{H})$. (b) Partition function of internal rotor calculated from eigenstate energies ( $\left.Q_{\text {exact }}\right)$, harmonic oscillator of lowest conformer $\left(Q_{\mathrm{HO}}\right)$, harmonic oscillator of all conformers $\left(Q_{\mathrm{HO}^{+}} Q^{\prime}{ }_{\mathrm{Ho}}\right)$, and Pitzer-Gwinn $\left(Q_{\mathrm{PG}}\right)$ approximations, (c) chemical structure at dihedral angle $D(\mathrm{C}-\mathrm{C}-\mathrm{O}-\mathrm{H})=0$.

\section{A2. Potential Energy Surface at 0 K}

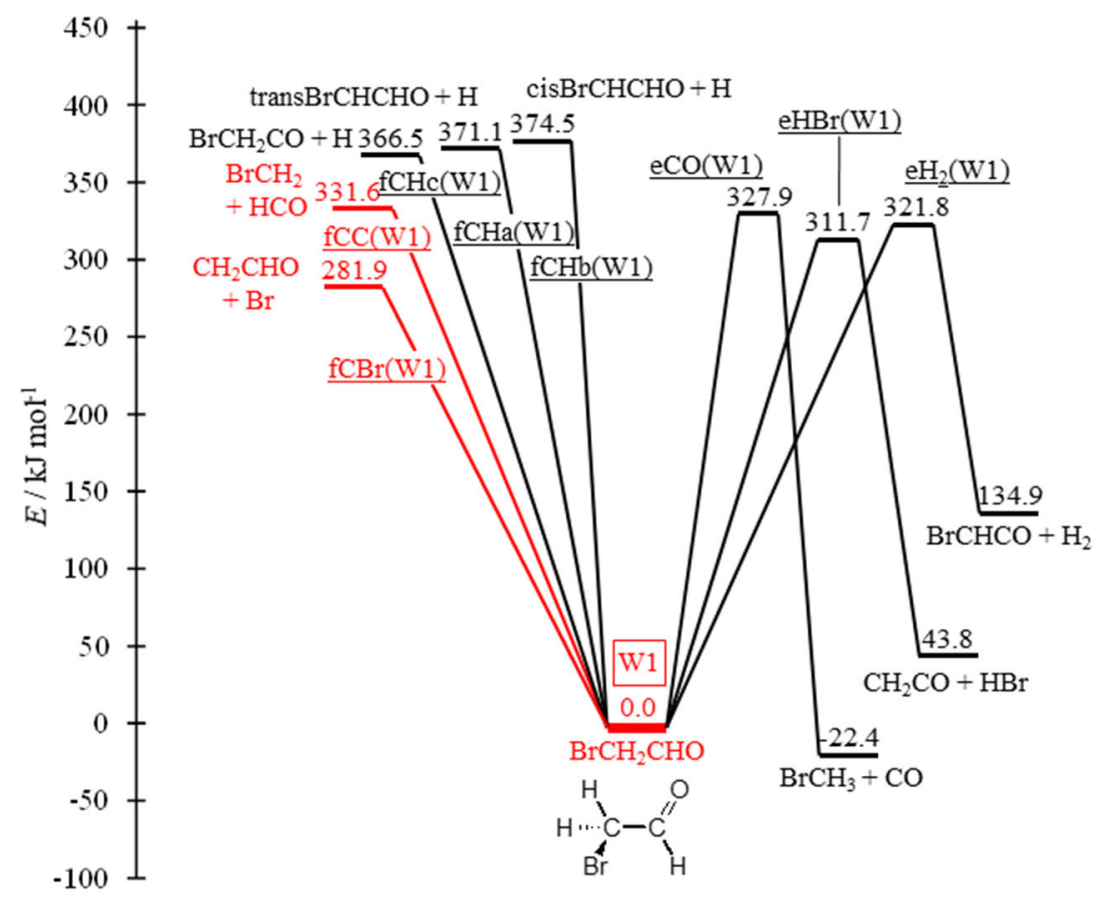

Figure S4. Energy diagram of bond fission and molecular elimination reactions of $\mathrm{BrCH}_{2} \mathrm{CHO}$ calculated on $\mathrm{CCSD}(\mathrm{T}) / \mathrm{CBS}$ level of theory. The stated values are enthalpies relative to $\mathrm{BrCH}_{2} \mathrm{CHO}$ at $0 \mathrm{~K}$. The underlined abbreviations are used to designate the various reaction channels, the framed abbreviation Wx designates the potential energy well $\mathrm{x}$ (see also Fig S6). The reaction channels colored in red are included in the RRKM/master equation analyses. 


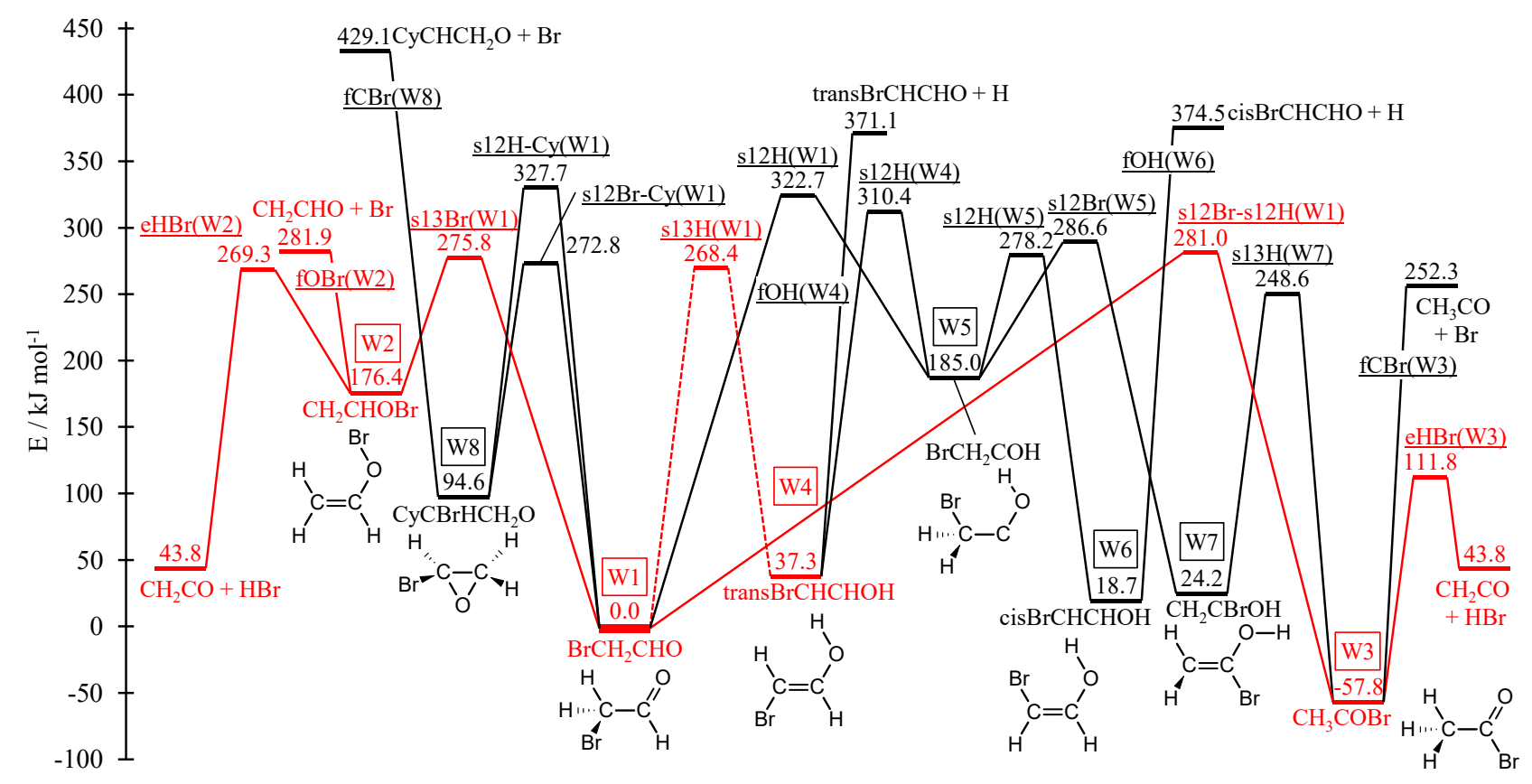

Figure S5. Energy diagram of atom shift reactions of $\mathrm{BrCH}_{2} \mathrm{CHO}$ and subsequent reactions of products calculated on $\mathrm{CCSD}(\mathrm{T}) / \mathrm{CBS}$ level of theory. The stated values are enthalpies relative to $\mathrm{BrCH}_{2} \mathrm{CHO}$ at $0 \mathrm{~K}$. The underlined abbreviations are used to designate the various reaction channels, the framed abbreviation $\mathrm{Wx}$ designates the potential energy well $\mathrm{x}$ (see also Fig S6). The reaction channels colored in red are included in the RRKM/master equation analyses, the dashed $\mathrm{s} 13 \mathrm{H}(\mathrm{W} 1)$ channel has only been considered in the analysis of the photoactivated process. 


\section{A3. Molecular Structures}
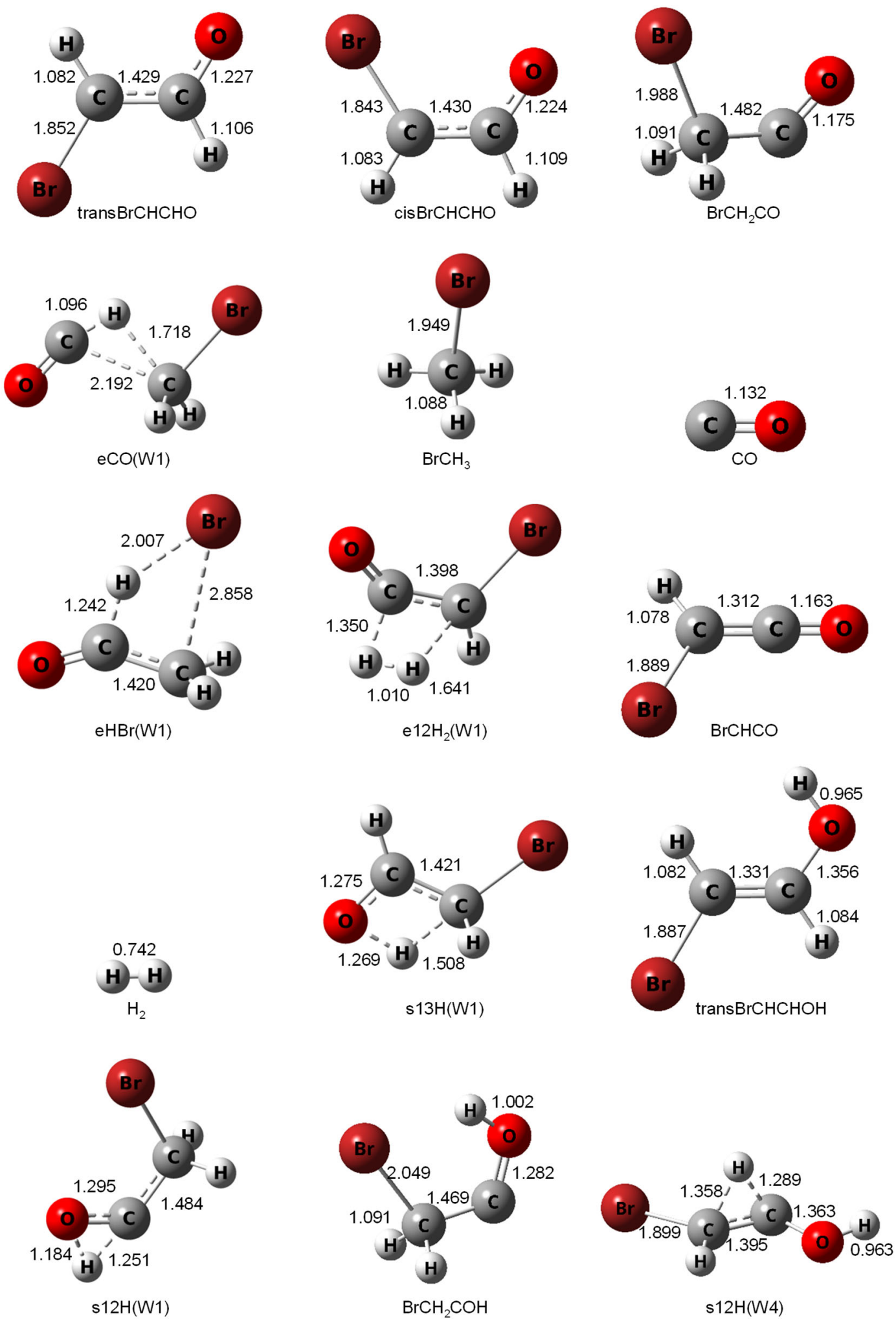

Figure S6. Optimized structures of the reactant, products, and transition-states calculated at the B3LYP/6$31 \mathrm{G}(2 \mathrm{~d}, \mathrm{p})$ level of theory. The numbers denote the bond lengths in units of ångström. 


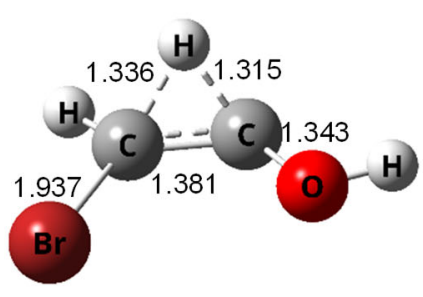

s12H(W5)

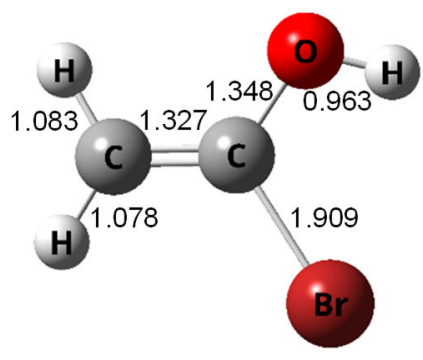

$\mathrm{CH}_{2} \mathrm{CBrOH}$

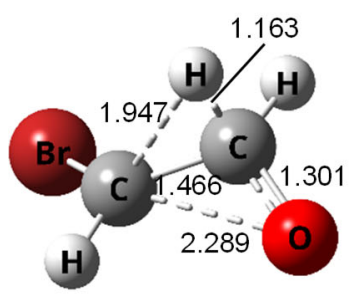

s12H-Cy(W1)

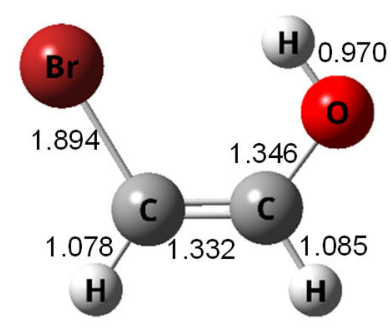

cisBrCHCHOH

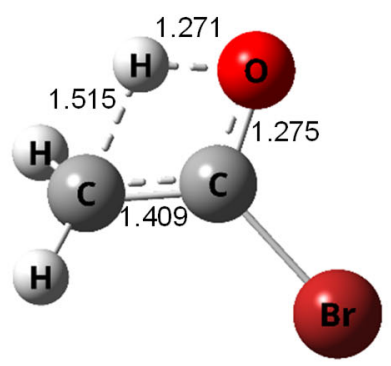

s13H(W7)

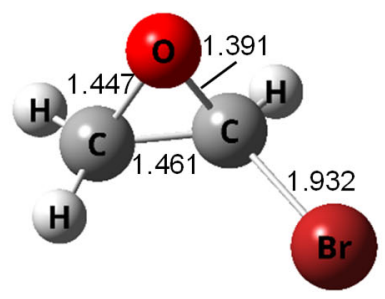

CyCBrHCH2O

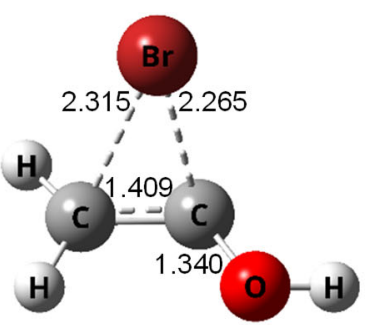

s12Br(W5)

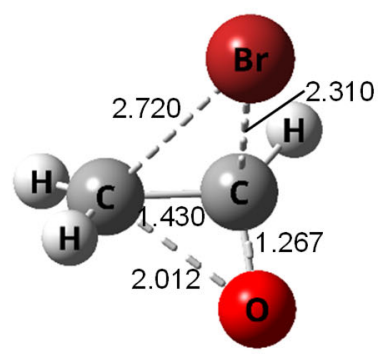

s12Br-Cy(W1)

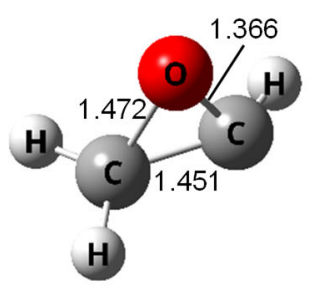

CyCHCH2O

Figure S6 (continued). Optimized structures of the reactant, products, and transition-states calculated at B3LYP/6-31G(2d,p) level of theory. The numbers denote the bond lengths in units of angström. 
Table S1. Cartesian coordinate of the optimized reactant, products, and transition-states structure. ${ }^{a, b}$

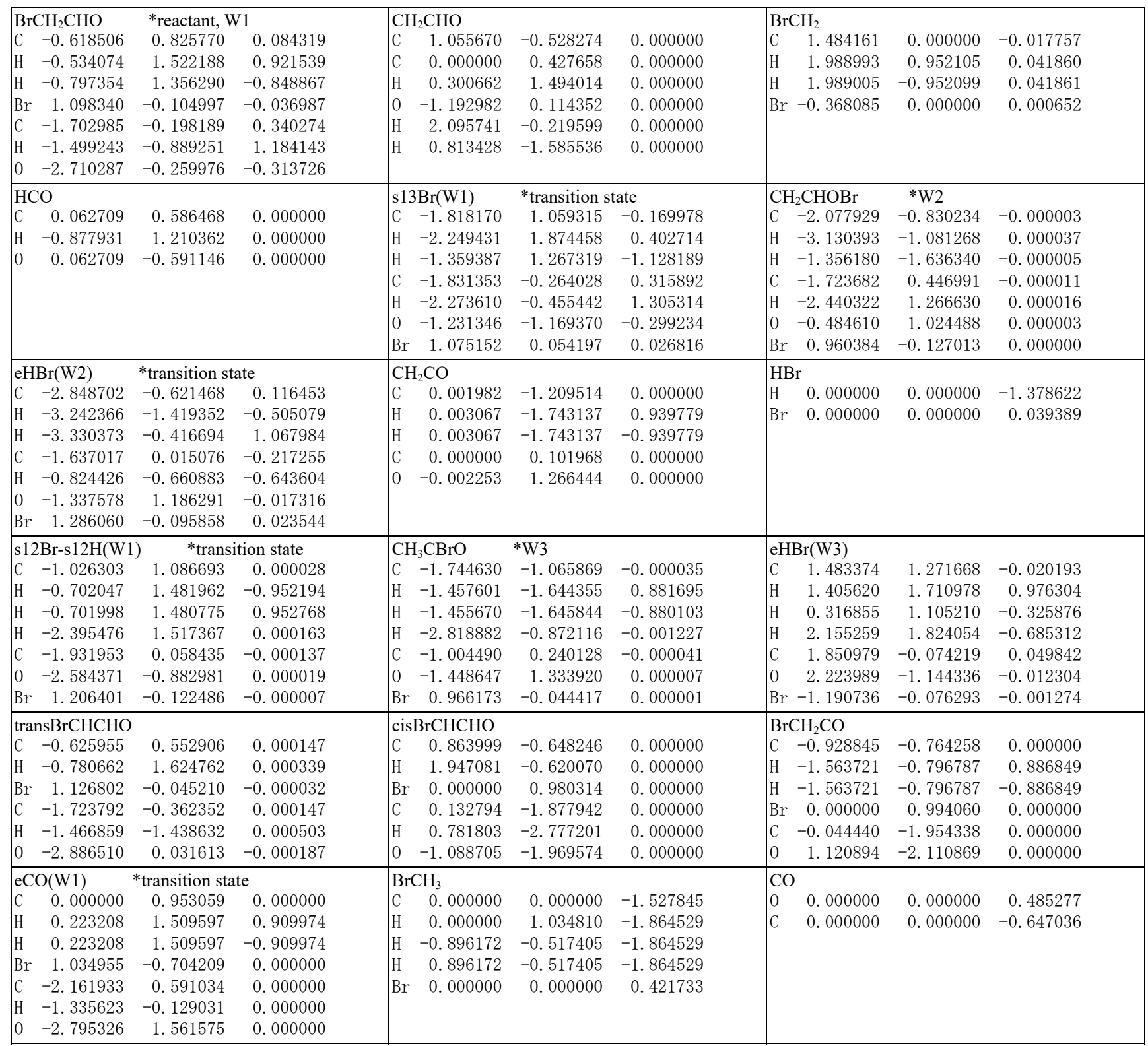

(Table S1 continued) 
Table S1 (continued). Cartesian coordinate of the optimized structure of the species not included in RRKM/master equation analysis. ${ }^{a, b}$

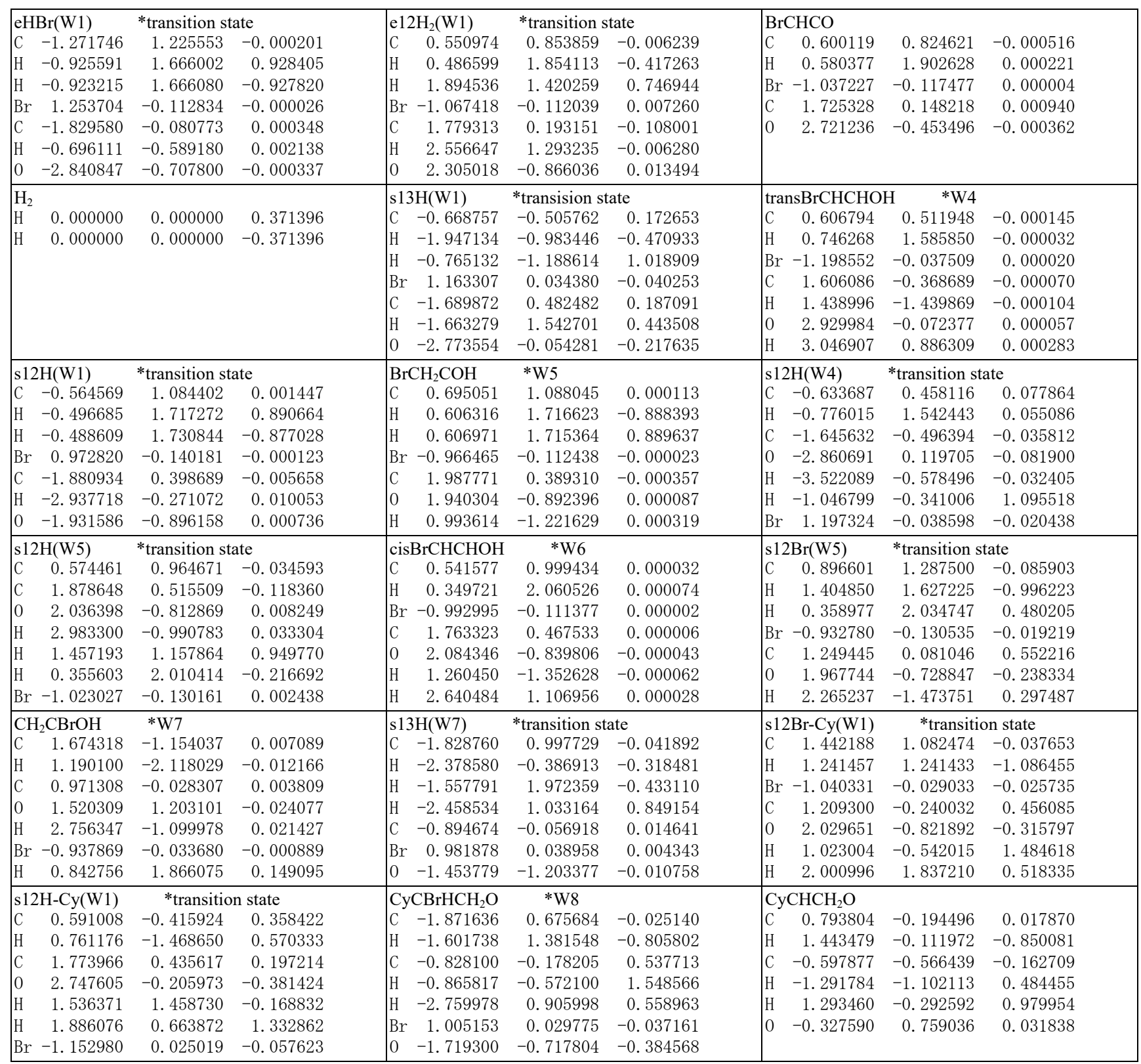

${ }^{a}$ Explanation of the abbreviations for the reaction channels is given in Figs. 2 and 3 in the main text.

${ }^{b}$ Optimized structures have been calculated using the method of B3LYP/6-31G(2d,p). 


\section{A4. Molecular Constants}

Table S2. Vibrational frequencies of the optimized reactant, products, and transition-states structure.

\begin{tabular}{|c|c|}
\hline species $^{\text {a }}$ & $v / \mathrm{cm}^{-1} b, c$ \\
\hline $\mathrm{BrCH}_{2} \mathrm{CHO}$ & $\begin{array}{lllllllllllllll}74 & 263 & 437 & 628 & 801 & 982 & 1051 & 1162 & 1217 & 1418 & 1453 & 1829 & 2928 & 3088 & 3179\end{array}$ \\
\hline $\mathrm{CH}_{2} \mathrm{CHO}$ & $453 \quad 500748 \quad 977 \quad 979 \quad 1159 \quad 1406 \quad 1478 \quad 1566 \quad 2938 \quad 3152 \quad 3269$ \\
\hline $\mathrm{BrCH}_{2}$ & 136719935139531813336 \\
\hline $\mathrm{HCO}$ & 111819402638 \\
\hline $\mathrm{s} 13 \mathrm{Br}(\mathrm{W} 1)$ & $\begin{array}{lllllllllllllll}\text { i617 } & 178 & 228 & 481 & 543 & 850 & 984 & 1011 & 1171 & 1384 & 1448 & 1495 & 3020 & 3168 & 3292\end{array}$ \\
\hline $\mathrm{CH}_{2} \mathrm{CHOBr}$ & $\begin{array}{lllllllllllllll}205 & 231 & 515 & 654 & 699 & 837 & 937 & 958 & 1139 & 1335 & 1430 & 1711 & 3163 & 3187 & 3276\end{array}$ \\
\hline eHBr(W2) & $\begin{array}{lllllllllllllll}\text { i925 } & 113 & 159 & 352 & 464 & 585 & 928 & 1023 & 1146 & 1259 & 1467 & 1608 & 2423 & 3152 & 3265\end{array}$ \\
\hline $\mathrm{CH}_{2} \mathrm{CO}$ & $448 \quad 523 \quad 583 \quad 996 \quad 1174 \quad 1422 \quad 2235 \quad 3195 \quad 3292$ \\
\hline $\mathrm{HBr}$ & 2683 \\
\hline s12Br-s12H(W1) & $\begin{array}{lllllllllllllll}\text { i11193 } & 76 & 324 & 336 & 428 & 589 & 975 & 981 & 1028 & 1110 & 1338 & 1441 & 2260 & 3190 & 3324\end{array}$ \\
\hline $\mathrm{CH}_{3} \mathrm{CBrO}$ & $\begin{array}{lllllllllllllll}145 & 298 & 338 & 499 & 569 & 951 & 1041 & 1104 & 1387 & 1467 & 1470 & 1914 & 3058 & 3138 & 3158\end{array}$ \\
\hline eHBr(W3) & $\begin{array}{lllllllllllllll}\text { i746 } & 143 & 224 & 351 & 422 & 784 & 958 & 1030 & 1103 & 1300 & 1405 & 1750 & 2273 & 3068 & 3156\end{array}$ \\
\hline transBrCHCHO & 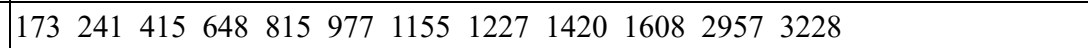 \\
\hline cisBrCHCHO & $\begin{array}{llllllllllll}183 & 309 & 565 & 606 & 782 & 957 & 1063 & 1312 & 1409 & 1615 & 2928 & 3217\end{array}$ \\
\hline $\mathrm{BrCH}_{2} \mathrm{CO}$ & $\begin{array}{llllllllllll}145 & 214 & 494 & 597 & 746 & 846 & 1147 & 1208 & 1417 & 1975 & 3101 & 3160\end{array}$ \\
\hline $\mathrm{eCO}(\mathrm{W} 1)$ & $\begin{array}{lllllllllllllll}1653 & 90 & 95 & 227 & 466 & 583 & 688 & 980 & 995 & 1006 & 1386 & 1935 & 3084 & 3089 & 3194\end{array}$ \\
\hline $\mathrm{BrCH}_{3}$ & 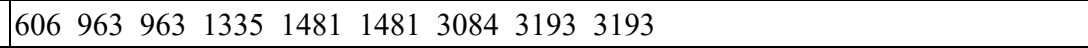 \\
\hline $\mathrm{CO}$ & 2202 \\
\hline $\mathrm{eHBr}(\mathrm{W} 1)$ & $\begin{array}{lllllllllllllll}\text { i1613 } & 203 & 239 & 291 & 361 & 592 & 697 & 811 & 1063 & 1075 & 1427 & 1533 & 1931 & 3172 & 3280\end{array}$ \\
\hline $\mathrm{e} 12 \mathrm{H}_{2}(\mathrm{~W} 1)$ & i1549 $171329454 \quad 572 \quad 646 \quad 764 \quad 961 \quad 1120 \quad 1246 \quad 1297 \quad 1426 \quad 1942 \quad 2046 \quad 3219$ \\
\hline $\mathrm{BrCHCO}$ & $156442524530747 \quad 1124 \quad 1309 \quad 2233 \quad 3263$ \\
\hline $\mathrm{H}_{2}$ & 4465 \\
\hline $\mathrm{s} 13 \mathrm{H}(\mathrm{W} 1)$ & 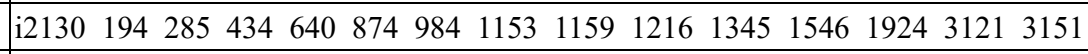 \\
\hline transBrCHCHOH & $\begin{array}{lllllllllllllll}230 & 242 & 390 & 460 & 760 & 803 & 972 & 1140 & 1208 & 1332 & 1380 & 1702 & 3210 & 3218 & 3798\end{array}$ \\
\hline $\mathrm{s} 12 \mathrm{H}(\mathrm{W} 1)$ & i2008 $170 \begin{array}{lllllllllllll}196 & 511 & 525 & 721 & 766 & 899 & 1105 & 1218 & 1399 & 1467 & 2647 & 3078 & 3131\end{array}$ \\
\hline $\mathrm{BrCH}_{2} \mathrm{COH}$ & $\begin{array}{lllllllllllllll}231 & 249 & 395 & 648 & 706 & 910 & 957 & 1097 & 1173 & 1391 & 1422 & 1464 & 3100 & 3147 & 3161\end{array}$ \\
\hline $\mathrm{s} 12 \mathrm{H}(\mathrm{W} 4)$ & 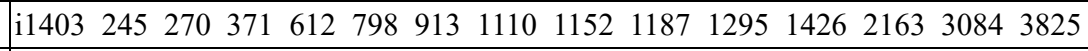 \\
\hline $\mathrm{s} 12 \mathrm{H}(\mathrm{W} 5)$ & $\begin{array}{lllllllllllllll}\mathrm{i} 1295 & 157 & 451 & 508 & 646 & 690 & 772 & 1085 & 1223 & 1282 & 1349 & 1490 & 2116 & 3226 & 3815\end{array}$ \\
\hline cisBrCHCHOH & $\begin{array}{lllllllllllllll}189 & 394 & 543 & 549 & 699 & 760 & 915 & 1085 & 1217 & 1337 & 1395 & 1708 & 3197 & 3271 & 3716\end{array}$ \\
\hline s12Br(W5) & $\begin{array}{lllllllllllllll}\mathrm{i} 568 & 222 & 356 & 457 & 621 & 808 & 996 & 1039 & 1102 & 1279 & 1380 & 1515 & 3060 & 3266 & 3801\end{array}$ \\
\hline $\mathrm{CH}_{2} \mathrm{CBrOH}$ & $\begin{array}{lllllllllllllll}105 & 333 & 365 & 516 & 588 & 715 & 821 & 986 & 1167 & 1295 & 1431 & 1737 & 3184 & 3296 & 3831\end{array}$ \\
\hline $\mathrm{s} 13 \mathrm{H}(\mathrm{W} 7)$ & 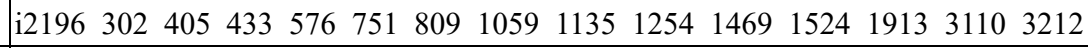 \\
\hline $\mathrm{s} 12 \mathrm{Br}-\mathrm{Cy}(\mathrm{W} 1)$ & 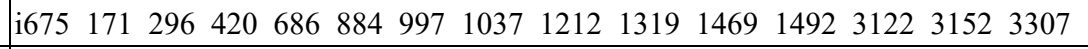 \\
\hline s12H-Cy(W1) & $\begin{array}{lllllllllllllll}\text { i633 } & 224 & 250 & 417 & 732 & 785 & 1026 & 1124 & 1177 & 1232 & 1275 & 1349 & 2390 & 2869 & 3198\end{array}$ \\
\hline $\mathrm{CyCBrHCH}_{2} \mathrm{O}$ & $\begin{array}{lllllllllllllll}291 & 329 & 566 & 822 & 911 & 1008 & 1087 & 1149 & 1168 & 1278 & 1335 & 1523 & 3108 & 3169 & 3209\end{array}$ \\
\hline $\mathrm{CyCHCH}_{2} \mathrm{O}$ & $\begin{array}{llllllllllll}781 & 812 & 942 & 1048 & 1081 & 1127 & 1187 & 1355 & 1529 & 3099 & 3127 & 3193\end{array}$ \\
\hline
\end{tabular}

${ }^{a}$ Explanation of the abbreviations for the reaction channels is given in Figs. 2 and 3 in the main text.

${ }^{b}$ Optimized structures have been calculated by using the method of B3LYP/6-31G(2d,p).

${ }^{c}$ Imaginary frequency in transition-state is shown by "i". 
Table S3. Rotational constants of the optimized reactant, products, and transition-states structure.

\begin{tabular}{|c|c|c|c|}
\hline species $^{a}$ & $A / \mathrm{cm}^{-1} b$ & $B / \mathrm{cm}^{-1 b}$ & $C / \mathrm{cm}^{-1 b}$ \\
\hline $\mathrm{BrCH}_{2} \mathrm{CHO}$ & 0.779 & 0.065 & 0.063 \\
\hline $\mathrm{CH}_{2} \mathrm{CHO}$ & 2.246 & 0.382 & 0.326 \\
\hline $\mathrm{BrCH}_{2}$ & 9.193 & 0.378 & 0.364 \\
\hline $\mathrm{HCO}$ & 23.233 & 1.495 & 1.404 \\
\hline s13Br(W1) & 0.353 & 0.080 & 0.068 \\
\hline $\mathrm{CH}_{2} \mathrm{CHOBr}$ & 0.494 & 0.094 & 0.079 \\
\hline $\mathrm{eHBr}(\mathrm{W} 2)$ & 0.513 & 0.054 & 0.050 \\
\hline $\mathrm{CH}_{2} \mathrm{CO}$ & 9.470 & 0.343 & 0.331 \\
\hline $\mathrm{HBr}$ & 8.425 & & \\
\hline s12Br-s12H(W1) & 0.467 & 0.059 & 0.053 \\
\hline $\mathrm{CH}_{3} \mathrm{CBrO}$ & 0.337 & 0.100 & 0.078 \\
\hline eHBr(W3) & 0.340 & 0.064 & 0.054 \\
\hline transBrCHCHO & 1.659 & 0.061 & 0.059 \\
\hline cisBrCHCHO & 0.568 & 0.086 & 0.075 \\
\hline $\mathrm{BrCH}_{2} \mathrm{CO}$ & 0.512 & 0.081 & 0.071 \\
\hline $\mathrm{eCO}(\mathrm{W} 1)$ & 0.887 & 0.048 & 0.046 \\
\hline $\mathrm{BrCH}_{3}$ & 5.207 & 0.317 & 0.317 \\
\hline $\mathrm{CO}$ & 1.918 & & \\
\hline eHBr(W1) & 0.486 & 0.053 & 0.049 \\
\hline $\mathrm{e} 12 \mathrm{H}_{2}(\mathrm{~W} 1)$ & 0.566 & 0.074 & 0.066 \\
\hline $\mathrm{BrCHCO}$ & 1.029 & 0.069 & 0.065 \\
\hline $\mathrm{H}_{2}$ & 60.633 & & \\
\hline $\mathrm{s} 13 \mathrm{H}(\mathrm{W} 1)$ & 1.212 & 0.061 & 0.059 \\
\hline transBrCHCHOH & 1.627 & 0.057 & 0.055 \\
\hline $\mathrm{s} 12 \mathrm{H}(\mathrm{W} 1)$ & 0.445 & 0.089 & 0.075 \\
\hline $\mathrm{BrCH}_{2} \mathrm{COH}$ & 0.435 & 0.089 & 0.075 \\
\hline $\mathrm{s} 12 \mathrm{H}(\mathrm{W} 4)$ & 1.672 & 0.057 & 0.056 \\
\hline $\mathrm{s} 12 \mathrm{H}(\mathrm{W} 5)$ & 0.500 & 0.082 & 0.071 \\
\hline cisBrCHCHOH & 0.494 & 0.086 & 0.073 \\
\hline s12Br(W5) & 0.377 & 0.099 & 0.083 \\
\hline $\mathrm{CH}_{2} \mathrm{CbrOH}$ & 0.349 & 0.105 & 0.081 \\
\hline $\mathrm{s} 13 \mathrm{H}(\mathrm{W} 7)$ & 0.409 & 0.097 & 0.079 \\
\hline s12Br-Cy(W1) & 0.438 & 0.081 & 0.073 \\
\hline s12H-Cy(W1) & 1.022 & 0.060 & 0.060 \\
\hline $\mathrm{CyCBrHCH}_{2} \mathrm{O}$ & 0.638 & 0.086 & 0.083 \\
\hline $\mathrm{CyCHCH}_{2} \mathrm{O}$ & 0.998 & 0.790 & 0.498 \\
\hline
\end{tabular}

${ }^{a}$ Explanation of the abbreviations for the reaction channels is given Figs. 2 and 3 in the main text.

${ }^{b}$ Optimized structures have been calculated using the method of B3LYP/6-31G(2d,p). 
Table S4. $T_{1}$ diagnostics for the reactant, products, and transition-states calculations.

\begin{tabular}{|c|c|}
\hline species $^{a}$ & $T_{1}{ }^{b}$ \\
\hline $\mathrm{BrCH}_{2} \mathrm{CHO}$ & 0.011 \\
\hline $\mathrm{CH}_{2} \mathrm{CHO}$ & 0.032 \\
\hline $\mathrm{BrCH}_{2}$ & 0.013 \\
\hline $\mathrm{HCO}$ & 0.021 \\
\hline s13Br(W1) & 0.074 \\
\hline $\mathrm{CH}_{2} \mathrm{CHOBr}$ & 0.012 \\
\hline eHBr(W2) & 0.068 \\
\hline $\mathrm{CH}_{2} \mathrm{CO}$ & 0.016 \\
\hline $\mathrm{HBr}$ & 0.006 \\
\hline s12Br-s12H(W1) & 0.015 \\
\hline $\mathrm{CH}_{3} \mathrm{CBrO}$ & 0.012 \\
\hline eHBr(W3) & 0.014 \\
\hline transBrCHCHO & 0.026 \\
\hline cisBrCHCHO & 0.026 \\
\hline $\mathrm{BrCH}_{2} \mathrm{CO}$ & 0.016 \\
\hline $\mathrm{eCO}(\mathrm{W} 1)$ & 0.022 \\
\hline $\mathrm{BrCH}_{3}$ & 0.007 \\
\hline $\mathrm{CO}$ & 0.018 \\
\hline eHBr(W1) & 0.043 \\
\hline $\mathrm{e} 12 \mathrm{H}_{2}(\mathrm{~W} 1)$ & 0.014 \\
\hline $\mathrm{BrCHCO}$ & 0.012 \\
\hline $\mathrm{H}_{2}$ & 0.005 \\
\hline s13H(W1) & 0.015 \\
\hline transBrCHCHOH & 0.010 \\
\hline s12H(W1) & 0.015 \\
\hline $\mathrm{BrCH}_{2} \mathrm{COH}$ & 0.014 \\
\hline s12H(W4) & 0.014 \\
\hline s12H(W5) & 0.015 \\
\hline cisBrCHCHOH & 0.010 \\
\hline s12Br(W5) & 0.024 \\
\hline $\mathrm{CH}_{2} \mathrm{CbrOH}$ & 0.010 \\
\hline s13H(W7) & 0.014 \\
\hline s12Br-Cy(W1) & 0.030 \\
\hline s12H-Cy(W1) & 0.062 \\
\hline $\mathrm{CyCBrHCH}_{2} \mathrm{O}$ & 0.010 \\
\hline $\mathrm{CyCHCH}_{2} \mathrm{O}$ & 0.018 \\
\hline
\end{tabular}

a . Explanation of the abbreviations for the reaction channels is given in Figs. 2 and 3 in the main text.

${ }^{b} T_{1}$ diagnostic value in CCSD(T)/aug-cc-pvqz//B3LYP/6-31G(2d,p). 


\section{B. Potential Energy Surface: Discussion of Minor Reaction Channels}

Here, we add a brief discussion of those reaction channels that are not included in the main text and that are predicted to have a minor contribution to the overall unimolecular dissociation of $\mathrm{BrCH}_{2} \mathrm{CHO}$. For an explanation of the terminology used to name the reaction channels see main text and Figs. 2, 3, S4, and S5. In order to be consistent with the main text and Figs. 2 and 3, in the following all energy differences are reported in terms of $\Delta H^{\circ}{ }_{298 \mathrm{~K}}$.

\section{B1. Direct Bond Fission}

\section{$\mathrm{fCHa}(\mathrm{W} 1), \mathrm{fCHb}(\mathrm{W} 1)$, and $\mathrm{fCHc}(\mathrm{W} 1)$ channels.}

The $\mathrm{fCHa}(\mathrm{W} 1), \mathrm{fCHb}(\mathrm{W} 1)$, and $\mathrm{fCHc}(\mathrm{W} 1)$ pathways involve relatively high enthalpies of reaction of 376.6, 379.5 , and $372.2 \mathrm{~kJ} \mathrm{~mol}^{-1}$, respectively. In contrast to acetaldehyde, where the aldehydic $\mathrm{CH}$ fission channel is known to contribute with a relative branching fraction of a few percent [1], these channels are not expected to play a significant role in the overall dissociation of $\mathrm{BrCH}_{2} \mathrm{CHO}$. Note that the $\mathrm{C}-\mathrm{H} \mathrm{BDE}$ in $\mathrm{CH}_{2} \mathrm{Br}$-group ( $\mathrm{fCHa}(\mathrm{W} 1)$ and $\mathrm{fCHb}(\mathrm{W} 1)$ ) is weakened by bromine substitution, compared to the $\mathrm{CH}_{3}$-group in $\mathrm{CH}_{3} \mathrm{CHO}$ $\left(400.0 \pm 1.7 \mathrm{~kJ} \mathrm{~mol}^{-1}[2]\right)$, but the aldehydic $\mathrm{C}-\mathrm{H}$ bond $(\mathrm{fCHc}(\mathrm{W} 1))$ is not affected $\left(373.6 \pm 1.7 \mathrm{~kJ} \mathrm{~mol}^{-1}\right.$ for $\left.\mathrm{CH}_{3} \mathrm{CHO}\right)$.

\section{B2. Molecular Elimination}

\section{eHBr(W1) and $\mathrm{eH}_{2}(\mathrm{~W} 1)$ channels}

The 1,2-HBr elimination channel with an endothermicity of $49.1 \mathrm{~kJ} \mathrm{~mol}^{-1}$ involves a four-membered ring tight transition state located at $312.5 \mathrm{~kJ} \mathrm{~mol}^{-1}$. The 1,2- $\mathrm{H}_{2}$ elimination channel involves high endothermicity of 142.1 $\mathrm{kJ} \mathrm{mol}^{-1}$ and an energetically even higher four-membered ring tight transition state at $321.3 \mathrm{~kJ} \mathrm{~mol}^{-1}$. The high energy barriers make both eliminations to highly improbable decomposition channels at thermal energies. Indicating a substantial bromine effect, the calculated energy barrier is lowered by $\approx 17 \mathrm{~kJ} \mathrm{~mol}^{-1}$ compared to the $\mathrm{H}_{2}$ elimination in acetaldehyde, for which Martell et al. [3] and Harding et al. [4] reported theoretical barriers of $340 \mathrm{~kJ} \mathrm{~mol}^{-1}$ and $336.4 \mathrm{~kJ} \mathrm{~mol}^{-1}$, respectively. Note that the channel $\mathrm{eH}_{2}(\mathrm{~W} 1)$, which can also take place as a H-atom roaming reaction, has been recently found to contribute to acetaldehyde photolysis at a wavelength of $305.6 \mathrm{~nm}$, but only with a low relative branching fraction of $<1 \%$ [5].

\section{eCO(W1) channel}

The exothermic $\left(\Delta_{\mathrm{rxn}} H=-17.1 \mathrm{~kJ} \mathrm{~mol}^{-1}\right)$ mechanism of $\mathrm{CO}$ elimination from $\mathrm{BrCH}_{2} \mathrm{CHO}$ involves elongation of the $\mathrm{C}-\mathrm{C}$ bond, then the $\mathrm{H}$ atom of the $\mathrm{CHO}$ fragment shifts to the $\mathrm{C}$ atom in $\mathrm{CH}_{2} \mathrm{Br}$ fragment via a threecenter TS with a bridging $\mathrm{H}$-atom. The reaction barrier of $330.8 \mathrm{~kJ} \mathrm{~mol}^{-1}$ is somewhat lower than the $346 \mathrm{~kJ}$ mol $^{-1}$ reported by Martell et al. [3] for $\mathrm{CO}$ elimination in $\mathrm{CH}_{3} \mathrm{CHO}$. In contrast, the exothermicity is about the same $\left(-17.1 \mathrm{~kJ} \mathrm{~mol}^{-1}\right.$ for $\mathrm{BrCH}_{2} \mathrm{CHO}$ versus $-21.3 \pm 0.4 \mathrm{~kJ} \mathrm{~mol}^{-1}$ for $\mathrm{CH}_{3} \mathrm{CHO}$ [2]), revealing that the existence of $\mathrm{Br}$ facilitates the transfer of the bridging $\mathrm{H}$-atom in the transition. Due to the energetically more favorable $\mathrm{Br}$ and $\mathrm{HBr}$ forming pathways discussed in the main text, this channel is not expected to be important for bromacetaldehyde photodissociation. However, for acetaldehyde it is known to be operative with a quantum yield up to $8 \%$ at lambda $=320 \mathrm{~nm}$, [1] where the reaction dynamics is dominated by $\mathrm{CH}_{3}$ roaming. [6]. 


\section{B3. Intramolecular Atomic Shift}

\section{s12H(W1) channel.}

The 1,2-hydrogen shift reaction, s12H(W1) correspond to the shift of the hydrogen atom of the carbonyl to the oxygen atom, forming $\mathrm{BrCH}_{2} \mathrm{COH}$. s12H(W1) involves three-membered tight transition states (see Fig. 3) located at $322.6 \mathrm{~kJ} \mathrm{~mol}^{-1}$. The $\mathrm{s} 12 \mathrm{H}(\mathrm{W} 1)$ channel is the first isomerization in the two-step isomerization through the s12Br(W5) and $\mathrm{s} 13 \mathrm{H}(\mathrm{W} 7)$ towards $\mathrm{CH}_{3} \mathrm{COBr}$. This pathway - together with the four-step isomerization starting from $\mathrm{s} 13 \mathrm{H}(\mathrm{W} 1)$ through $\mathrm{s} 12 \mathrm{H}(\mathrm{W} 4), \mathrm{s} 12 \mathrm{Br}(\mathrm{W} 5)$, and $\mathrm{s} 13 \mathrm{H}(\mathrm{W} 7)$ forming $\mathrm{CH}_{3} \mathrm{COBr}$ as well - are not considered in the kinetic analysis due to their high reaction barriers. Note that the two and four step isomerization pathways of $\mathrm{BrCH}_{2} \mathrm{CHO}$ towards $\mathrm{CH}_{3} \mathrm{COBr}$ share the pathway from W5 $\rightarrow$ W7 $\rightarrow$ W3. Also note that the $\mathrm{BrCH}_{2} \mathrm{COH}$ intermediate of $\mathrm{W} 5$ has an additional negligible exit channel via s12H(W5) and $\mathrm{fOH}(\mathrm{W} 6)$, forming cisBrCHCHO $+\mathrm{H}$ with a very high energy of $379.5 \mathrm{~kJ} \mathrm{~mol}^{-1}$.

\section{s12H-Cy(W1) and s12Br-Cy(W1) channels.}

These channels involve 1,2-hydrogen $(\mathrm{s} 12 \mathrm{H}-\mathrm{Cy}(\mathrm{W} 1))$ or 1,2-bromine (s12Br-Cy(W1)) shift reactions and cyclization resulting in a $\mathrm{C}-\mathrm{C}-\mathrm{O}$ ring structure. Although the reaction barrier of $\mathrm{s} 12 \mathrm{Br}-\mathrm{Cy}(\mathrm{W} 1)$ is relatively low, $274 \mathrm{~kJ} \mathrm{~mol}^{-1}$, the exit channel $\mathrm{fCBr}(\mathrm{W} 8)$ is very high in energy. Moreover, due to the high endothermicity of the $\mathrm{CyCBrHCH}_{2} \mathrm{O}$, intermediate population of well 8 (in microcanonical equilibrium) will be very low and hence both channels will play a very minor role for photochemical and thermal decomposition of $\mathrm{BrCH}_{2} \mathrm{CHO}$.

\section{References}

[1] Horowitz, A.; Calvert, J. G. Wavelength dependence of the primary processes in acetaldehyde photolysis. J. Phys. Chem. 1982, 86, 3105-3114.

[2] Vasiliou, A. K.;Piech, K. M.; Reed, B.; Zhang, X.; Nimlos, M. R.; Ahmed, M.; Golan, A.; Kostko, O.; Osborn, D. L.; David, D. E.; Urness, K. N.; Daily, J. W.; Stanton, J. F.; Ellison, G. B. Thermal decomposition of $\mathrm{CH}_{3} \mathrm{CHO}$ studied by matrix infrared spectroscopy and photoionization mass spectroscopy. J. Chem. Phys. 2012, 137, 164308-1/15.

[3] Martell. J.; Yu, H.;Goddard, J. Molecular decompositions of acetaldehyde and formamide: theoretical studies using Hartree-Fock. Mol. Phys. 1997, 92, 497-502.

[4] Harding, L. B.; Georgievskii, Y.; Klippenstein, S. J. Roaming Radical Kinetics in the Decomposition of Acetaldehyde. J. Phys. Chem. A 2010, 114, 765-777.

[5] Heazlewood, B. R.; Jordan, M. J. T.; Kable, S. H.; Selby, T. M.; Osborn, D. L.; Shepler, B. C.; Braams, B. J.; Bowman, J. M. Roaming is the dominant mechanism for molecular products in acetaldehyde photodissociation. Proc. Natl. Acad. Sci. 2008, 105, 12719-12724.

[6] Harrison, A. W.; Kharazmi, A.; Shaw, M. F.; Quinn, M. S.; Lee, K. L. K.; Nauta, K.; Rowell, K. N.; Jordan, M. J. T.; Kable, S. H. Dynamics and quantum yields of $\mathrm{H}_{2}+\mathrm{CH}_{2} \mathrm{CO}$ as a primary photolysis channel in CH3CHO. Phys. Chem. Chem. Phys. 2019, 21, 14284-14295. 


\section{UV Absorption Reference Spectra of Halogenated Acetaldehydes}

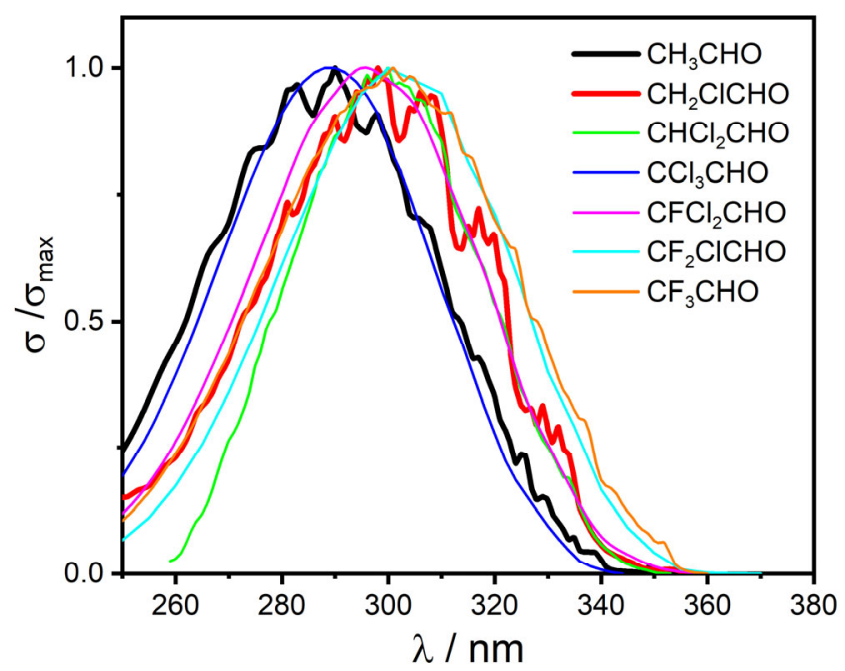

Figure S7. Absorption cross sections $\sigma$ of the $\left(\mathrm{n}, \pi^{*}\right)$ band of acetaldehyde in comparison with fluorine- and chlorine-substituted acetaldehydes. All data have been adopted from the JPL recommendation [1] and are normalized with respect to their respective maximum values $\sigma_{\max }$.

\section{Reference}

[1] Burkholder, J. B.;Sander, S. P.; Abbatt, J.; Barker, J. R.; Cappa, C.; Crounse, J. D.; Dibble, T. S.; Huie, R. E.; Kolb, C. E.; Kurylo, M. J.; Orkin, V. L.; Percival, C. J.; Wilmouth, D. M.; Wine, P.H. Chemical Kinetics and Photochemical Data for Use in Atmospheric Studies, Evaluation No. 19, JPL Publication 19-5, Jet Propulsion Laboratory, Pasadena, 2019 http://jpldataeval.jpl.nasa.gov. 


\section{Multi-Channel Thermal Unimolecular Decomposition Rate Constants}

\section{D1. Chebyshev Polynomials}

The complex temperature and pressure dependences of individual multi-channel rate constants can be accurately ${ }^{1}$ represented by Chebyshev polynomials according to $\log k(\widehat{T}, \hat{p})=\sum_{n=1}^{N} \sum_{m=1}^{M} a_{n m} \phi_{n}(\widehat{T}) \phi_{m}(\widehat{p}) . N=5$ and $M=5$ denote the number of basis functions $\phi$ along the normalized temperature and pressure axes, where the Chebyshev polynomials of the first kind are obtained from the recurrence relation $\phi_{0}(x)=1, \phi_{1}(x)=x$, and $\phi_{i+1}(x)=2 x \phi_{i}(x)-\phi_{i-1}(x)$. The reduced temperature and pressure are defined as

$$
\begin{gathered}
\hat{T}=\frac{2 T^{-1}-T_{\text {min }}^{-1}-T_{\text {max }}^{-1}}{T_{\text {max }}^{-1}-T_{\text {min }}^{-1}} \text { and } \\
\hat{p}=\frac{2 \log p-\log p_{\min }-\log p_{\max }}{\log p_{\max }-\log p_{\min }},
\end{gathered}
$$

hence yielding values in the interval $[-1: 1]$ with the max and min values defining the fitting range of the experimental data.

In the following, fitting parameters for the five main reaction channels are reported in CHEMKIN format, ${ }^{2}$ where TCHEB and PCHEB defines the fitting ranges for the temperature (in K) and pressure (in atm). The CHEB keyword specifies the dimension of the Chebyshev fit in the first line, followed by the $a_{n m}$ parameters in the order of $a_{11}, a_{12}, \ldots, a_{1 M}, \mathrm{a}_{21}, \ldots, a_{N M}$.

Note that the range of fitted pressures and temperatures is $1 \mathrm{mbar}<\mathrm{p}<1000$ bar and $500 \mathrm{~K}<T<2000 \mathrm{~K}$. Overall the Chebyshev fit is in agreement with the computed rate constant data within $<10 \%$ over the full parameter range.

\section{Channel W1-CH2CHO+Br (declare as DUPLICATE!)}

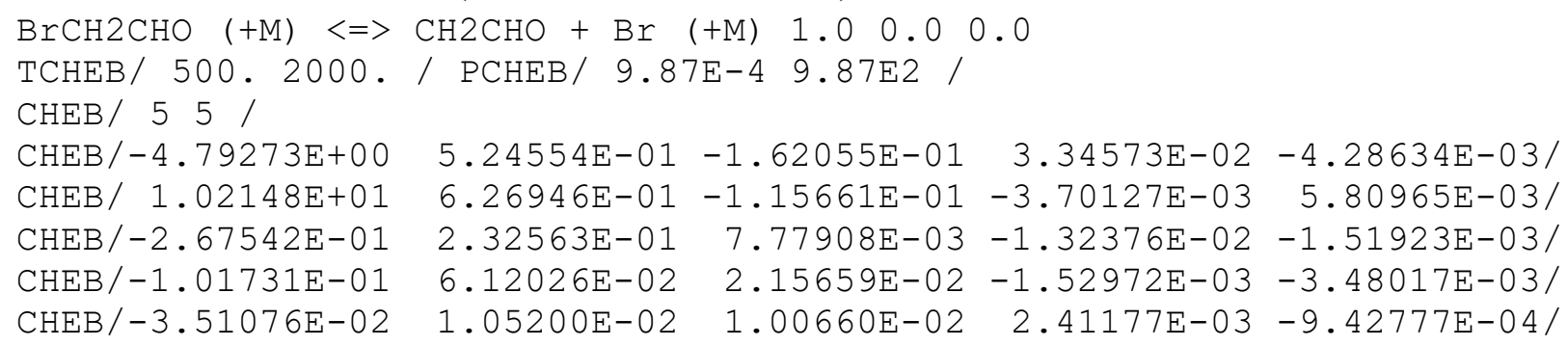

\section{Channel W1-BrCH2+HCO}

$\mathrm{BrCH} 2 \mathrm{CHO}(+\mathrm{M})<=>\mathrm{BrCH} 2+\mathrm{HCO}(+\mathrm{M}) 1.00 .00 .0$

$\mathrm{TCHEB} / 500$. 2000. / $\mathrm{PCHEB} / 9.87 \mathrm{E}-4$ 9.87E2 /

$\mathrm{CHEB} / 55$ /

$\begin{array}{lrrrrr}\mathrm{CHEB} /-7.09005 \mathrm{E}+00 & 2.54725 \mathrm{E}+00 & -1.07028 \mathrm{E}+00 & 2.72993 \mathrm{E}-01 & -2.49915 \mathrm{E}-02 / \\ \mathrm{CHEB} / \mathrm{1.22314E+01} & 3.85956 \mathrm{E}-01 & 2.89343 \mathrm{E}-01 & -2.17825 \mathrm{E}-01 & 4.35299 \mathrm{E}-02 / \\ \mathrm{CHEB} /-3.32528 \mathrm{E}-01 & 1.10944 \mathrm{E}-01 & 8.50560 \mathrm{E}-02 & -1.92535 \mathrm{E}-02 & -9.28297 \mathrm{E}-03 / \\ \mathrm{CHEB} /-1.15603 \mathrm{E}-01 & 2.11545 \mathrm{E}-02 & 2.11004 \mathrm{E}-02 & 3.27951 \mathrm{E}-03 & -1.38977 \mathrm{E}-03 / \\ \mathrm{CHEB} /-3.62272 \mathrm{E}-02 & 1.49066 \mathrm{E}-03 & 4.59661 \mathrm{E}-03 & 2.14942 \mathrm{E}-03 & 4.46771 \mathrm{E}-04 /\end{array}$


Channel W2-CH2CHO+Br (declare as DUPLICATE!)

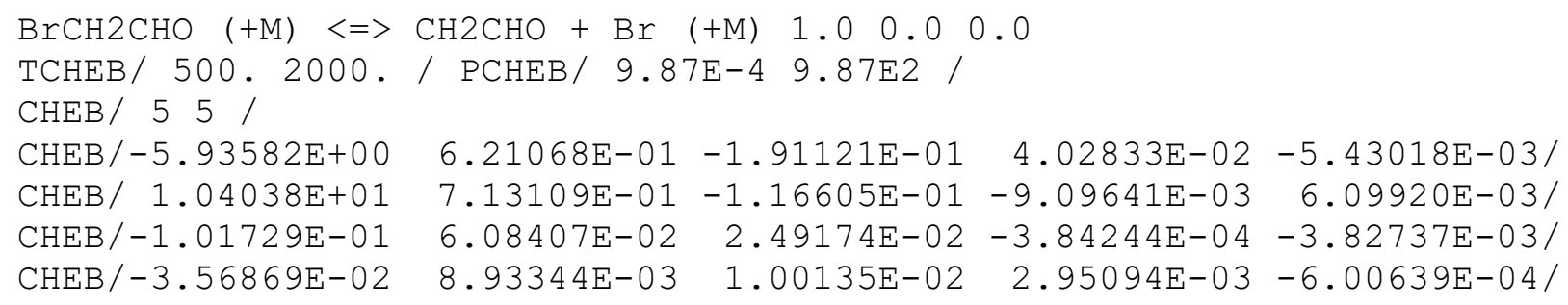

Channel W2-CH2CO+HBr (declare as DUPLICATE!)

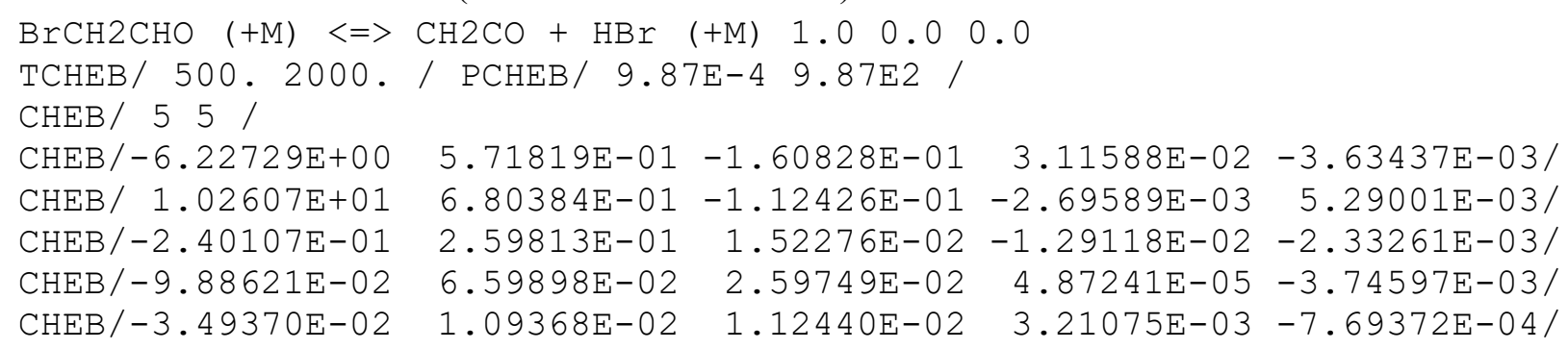

Channel W3-CH2CO+HBr (declare as DUPLICATE !)

$\mathrm{BrCH} 2 \mathrm{CHO}(+\mathrm{M}) \quad \Leftrightarrow \mathrm{CH} 2 \mathrm{CO}+\mathrm{HBr}(+\mathrm{M}) \quad 1.0 \quad 0.0 \quad 0.0$

TCHEB/ 500. 2000. / PCHEB/ 9.87E-4 9.87E2 /

CHEB / 55 /

$\mathrm{CHEB} /-5.52938 \mathrm{E}+00 \quad 7.31193 \mathrm{E}-01-2.17750 \mathrm{E}-01 \quad 4.39996 \mathrm{E}-02 \quad-5.19135 \mathrm{E}-03 /$

$\mathrm{CHEB} / 1.05650 \mathrm{E}+01 \quad 8.00077 \mathrm{E}-01-1.20061 \mathrm{E}-01-1.06335 \mathrm{E}-02 \quad 5.39049 \mathrm{E}-03 /$

$\mathrm{CHEB} /-2.39028 \mathrm{E}-01 \quad 2.57863 \mathrm{E}-01 \quad 2.92085 \mathrm{E}-02-1.44819 \mathrm{E}-02-4.53836 \mathrm{E}-03 /$

$\mathrm{CHEB} /-1.04765 \mathrm{E}-01 \quad 5.79209 \mathrm{E}-02 \quad 2.84999 \mathrm{E}-02 \quad 1.35028 \mathrm{E}-03 \quad-3.97411 \mathrm{E}-03 /$

$\mathrm{CHEB} /-3.57512 \mathrm{E}-02 \quad 7.70309 \mathrm{E}-03 \quad 9.92676 \mathrm{E}-03 \quad 3.36952 \mathrm{E}-03-1.66099 \mathrm{E}-04 /$

\section{References}

[1] Venkatesh, P. K.; Chang, A. Y.; Dean, A. M.; Cohen, M. H.; Carr, R. W. AIChE J. 1997, 43, 1331.

[2] Kee, R. J.; Rupley, F. M.; Miller, J. A.; Coltrin, M. E.; Grcar, J. F.; Meeks, E.; Moffat, H. K.; Lutz, A. E.; Dixon-Lewis, G.; Smooke, M. D.; Warnatz, J.; Evans, G. H.; Larson, R. S.; Mitchell, R. E.; Petzold, L. R.; Reynolds, W. C.; Caracotsios, M.; Stewart, W. E.; Glarborg, P.; Wang, C.; Adigun, O.; Houf, W. G.; Chou, C. P.; Miller, S. F.; Ho, P.; Young, D. J. Chemkin Release 4.0.1, Reaction Design, Inc., San Diego, CA, 2004. 


\section{D2. Chebyshev Script Manual}

For visualization of the multi-channel rate constants and branching ratio, as well as to facilitate the rate constants and branching ratios at a user-specified temperature and pressure, a gnuplot script along with a data file with computed rate constant data is provided as a separate Supplement file "cheby.zip". Note that gnuplot or wgnuplot source code or precompiled code for Windows OS, a program documentation, etc. is available free of charge at http://www.gnuplot.info/ (e.g., download precompiled Windows version via sourceforge).

The gnuplot script "cheby.gnu“" produces several graphs to illustrate the pressure and temperature dependences of the five considered thermal decomposition channels of bromoacetaldhyde. The fitted data are also directly compared with the original RRKM/ME rate constant data. All output is calculated based on the $5 \times 5$ Chebyshev polynomials given in section $\mathrm{C} 1$ of this Supplement.

\section{Files}

cheby.gnu gnuplot script file

alldata.out Table of calculated RRKM/ME rate constant data

\section{Usage}

I Unzip the zip-file "cheby.zip" into a dedicated folder.

II Install gnuplot/wgnuplot on your computer (version $>5.2$, see http://www.gnuplot.info/)

III Start the gnuplot program, navigate to your dedicated folder and then load the gnuplot script by typing "load "cheby.gnu" " and hit "RETURN".

IV Rate constant data and branching fractions are computed for the pre-selected temperature, $T=1000 \mathrm{~K}$, and pressure, $p=750$ Torr. $T$ and $p$ can be changed by simply editing the gnuplot script file "cheby.gnu" (lines 12/17).

V Many graphs are produced during the gnuplot script run, showing the following:

1 Overview plot of branching fractions for all channels at constant pressure.

2 Overview plot of branching fractions for all channels at constant temperature.

3-7 Comparison of fitted branching fractions and original RRKM/ME branching fractions, separately for each channel.

8-12 Fitted fall-off curves in comparison with original RRKM/ME result, separately for each channel. Note that the view can be changed in the script file.

13-17 T- $p$ surfaces with Chebyshev fit and total rate constant, separately for each channel. Note that the view can be changed in the script file, default is set to a projection view along the $p$ axis.

18 -22 Relative fitting errors of Chebyshev rate constant fit, separately for each channel. 
VI No guarantee is given that everything works properly! Please check program output by comparison with the rate constant data given in the paper!

VII The script file can be also used to refit the data, e.g. in case another $T$ and $p$-range is required. To do so, delete all lines with the fitted parameters, uncomment the lines with the "fit" command, and specify new fitting ranges in lines 29-32. 